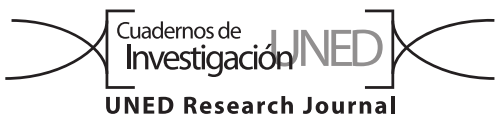

\title{
Culicoides (Diptera: Ceratopogonidae) from Ceará State, northeastern Brazil: Diversity, new records and bionomic approaches
}

\author{
Maria Luiza Felippe-Bauer', Gilmara P. Gonzaga', Robson C. Cavalcante², Ricristhi G. A. Gomes ${ }^{3}$ \\ \& Rafaella A. Silva ${ }^{4,5}$
}

1. Instituto Oswaldo Cruz-Fiocruz, Laboratório de Diptera, Coleção de Ceratopogonidae, Av. Brasil 4365, CEP 21040-900, Rio de Janeiro, RJ, Brazil; mlfbauer@ioc.fiocruz.br

2. Ministério da Saúde. Laboratório de Endemias - MS/4a CRES/SESA/CE, Rua 15 de novembro 973, CEP 62.760-000, Baturité, CE, Brazil; robsonccavalcante@yahoo.com

3. Secretaria de Saúde do estado do Ceará, Núcleo de Controle de Vetores, Rua dos Tabajaras 268, CEP 60060-510, Fortaleza, CE, Brazil; ricristhi.goncalves@saude.ce.gov.br

4. Ministério da Saúde, Secretaria de Vigilância em Saúde, SCS Quadra 4 Bloco A, CEP 70.304-000, Brasília, DF, Brazil; rafaella.silva@saude.gov.br

5. Universidade de Brasília, Campus Universitário Darcy Ribeiro, Núcleo de Medicina Tropical, CEP 70910-900, Brasília, DF, Brazil;

rafaella.silva@saude.gov.br

Received 14-IX-2018 • Corrected 13-XI-2018 • Accepted 15-XII-2018

\begin{abstract}
Introduction: little is known about the biodiversity of the genus Culicoides and the possible presence of vector species in Ceará State, Brazil. Objective: to improve the knowledge about the biodiversity and possible vectors presence in northeastern Brazil. Methods: with CDC light traps we surveyed Culicoides species in 18 municipalities from six mesoregions of Ceará State. Results: we collected 1453 specimens (12 species). Culicoides guyanensis was the most abundant species, with $75,84 \%$ of the collected specimens. Culicoides venezuelensis is well distributed and is found in five Mesoregions. We recorded five species for the first time from Ceará State and seven from the surveyed municipalities; the presence of species with sanitary importance is discussed. Conclusion: with the addition of new species records, there are now 12 species known from Ceará State. The presence of species with medical and/or veterinary importance in the studied Mesoregions is indicative of the need of epidemiological surveillance in this state.
\end{abstract}

Key words: biting midges, insect vectors, biodiversity, bionomy.
RESUMEN: "Culicoides (Diptera: Ceratopogonidae) del estado de Ceará, noreste de Brasil: Diversidad, nuevos registros y enfoques bionómicos". Introducción: poco se sabe sobre la biodiversidad del género Culicoides y la posible presencia de especies de vectores en el estado de Ceará, Brasil. Objetivo: mejorar el conocimiento de la biodiversidad y la posible presencia de vectores en el noreste de Brasil. Métodos: utilizamos trampas luminosas $C D C$, realizamos un levantamiento de las especies de Culicoides en 18 municipios pertenecientes a seis mesorregiones del estado de Ceará. Resultados: un total de 1453 ejemplares (12 especies) recolectamos. Culicoides guyanensis fue la especie más abundante correspondiendo al 75,84\% de los especímenes recolectados. Culicoides venezuelensis está bien distribuida en cinco de las mesorregiones investigadas. Cinco especies reportamos por primera vez para el estado de Ceará y siete especies para los municipios de las mesorregiones estudiadas; discutimos la presencia de especies de importancia sanitaria. Conclusión: con la adición de nuevos registros de especies, existen ahora 12 especies conocidas para el estado de Ceará. La presencia de especies con importancia médica y/o veterinaria en las mesorregiones estudiadas es indicativa de la necesidad de una vigilancia epidemiológica en el estado.

Palabras clave: jejenes, insectos vectores, biodiversidad, bionomia.
The genus Culicoides Latreille, 1809 includes 1368 extant species distributed worldwide (Borkent, 2016). Santarém and Felippe-Bauer (2018) listed 299 species from the Neotropical Region and 150 from Brazil. Ceará State is included in northeastern Brazil and despite occupying an area of $148016 \mathrm{~km}^{2}$, few studies was carried out on Culicoides in this state. Only Culicoides debilipalpis Lutz,
1913, C. guyanensis Floch \& Abonnenc, 1942, C. insignis Lutz, 1913, C. leopoldoi Ortiz, 1951, C. maruim Lutz, 1913, C. paraensis (Goeldi, 1905) and C. phlebotomus (Williston, 1896) have been reported from Ceará State (Santarém \& Felippe-Bauer, 2018). Of these, C. paraensis is considered the most important species of Ceratopogonidae in the Neotropics due to its vector role in Oropouche fever and 
its possible implication in the mansonelliasis transmission in Brazil and other Latin American countries. Also, C. insignis as well as C. pusillus Lutz, 1913 are incriminated as vector of Bluetongue in Central and South America.

The aim of this study is to provide a survey of Culicoides species in 18 municipalities of the six Mesoregions of Ceará to improving the knowledge about the biodiversity and possible vectors presence in northeastern Brazil.

\section{MATERIALS AND METHODS}

This survey was performed using CDC light traps in two moments, in the following Mesoregions of Ceara
State: Jaquaribe, Metropolitan of Fortaleza, North, Northwest, Sertões and South (Fig. 1). During 07 to 30 January 2008, collections were made in 13 municipalities of the mesoregions: Metropolitan of Fortaleza (Fortaleza 356'66"S \& 64³8'33"W, Aquiraz 390'00"S \& 38 36'66"W and Horizonte $\left.4^{\circ} 08^{\prime} 33^{\prime \prime} \mathrm{S} \& 38^{\circ} 48^{\prime} 33^{\prime \prime} \mathrm{W}\right)$, Jaguaribe (Aracati $4^{\circ} 55^{\prime} 00^{\prime \prime} \mathrm{S} \& 37^{\circ} 78^{\prime} 33^{\prime \prime} \mathrm{W}$, Limoeiro do Norte $5^{\circ} 15^{\prime} 00^{\prime \prime} \mathrm{S} \& 38^{\circ} 13^{\prime} 33^{\prime \prime} \mathrm{W}$ and Russas $4^{\circ} 91^{\prime} 66^{\prime \prime} \mathrm{S}$ \&

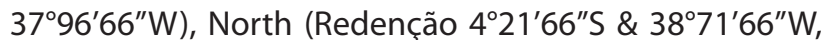
São Gonçalo do Amarante $3^{\circ} 60^{\prime} 00^{\prime \prime S}$ \& 38 $96^{\prime} 66^{\prime \prime} \mathrm{W}$ and Itapipoca $\left.3^{\circ} 48^{\prime} 33^{\prime \prime S} \& 39^{\circ} 58^{\prime} 33^{\prime \prime} W\right)$, Northwest (Barroquinha $2^{\circ} 98^{\prime} 33^{\prime \prime} \mathrm{S} \& 41^{\circ} 08^{\prime} 33^{\prime \prime} \mathrm{W}$ and Tianguá

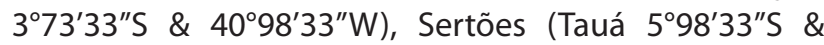
$40^{\circ} 28^{\prime} 33^{\prime \prime} \mathrm{W}$ ) and South (Juazeiro do Norte $7^{\circ} 20^{\prime} 00^{\prime \prime} \mathrm{S}$



Fig.1. Map of the Ceará State with indication of the 18 surveyed municipalities during 07 to 30 January 2008 and February 2013 to January 2014. Northwest Mesoregion: 1. Barroquinha, 2. Tianguá; North Mesoregion: 3. Itapipoca, 4. São Gonçalo do Amarante, 5. Pacoti, 6. Guaramiranga, 7. Mulungu, 8. Redenção, 9. Baturité, 10. Itapiuna; Metropolitan of Fortaleza Mesoregion: 11. Fortaleza, 12. Aquiraz, 13. Horizonte; Jaguaribe Mesoregion: 14. Aracati, 15. Russas, 16. Limoeiro do Norte; Sertões Mesoregion: 17. Tauá; South Mesoregion: 18. Juazeiro do Norte. 
\& $\left.39^{\circ} 33^{\prime} 33^{\prime \prime} W\right)$. The captures were made during three consecutive nights in the chosen localities. The captures were taking near the stable in the municipalities with livestock activities, and in the mangrove in costal municipalities. Captures of possible insect vectors is one of the actions of the Health Secretariat of Ceará State that does not required collection permit considering the Normative Instruction no. 141 of December 19, 2006 of the "Instituto Brasileiro do Meio Ambiente e dos Recursos Naturais Renováveis" (IBAMA).

During February 2013 to January 2014, collections were made in 11 localities of the five municipalities from North Mesoregion, as follows: Municipality of Baturité (Jordão $4^{\circ} 21^{\prime} 38^{\prime \prime} \mathrm{S} \& 38^{\circ} 54^{\prime} 73^{\prime \prime} \mathrm{W}$, Labirinto $4^{\circ} 17^{\prime} 73^{\prime \prime} \mathrm{S}$ \& $38^{\circ} 54^{\prime} 56^{\prime \prime} \mathrm{W}$ and Tijuca $4^{\circ} 18^{\prime} 16^{\prime \prime} \mathrm{S} \& 38^{\circ} 54^{\prime} 18^{\prime \prime} \mathrm{W}$ ), Municipality of Guaramiranga (Álvaro $4^{\circ} 17^{\prime} 33^{\prime \prime} S$ \& $38^{\circ} 57^{\prime} 00^{\prime \prime} \mathrm{W}$ and Granja Bonfim $4^{\circ} 14^{\prime} 24^{\prime \prime} \mathrm{S} \& 38^{\circ} 56^{\prime} 08^{\prime \prime} \mathrm{W}$ ), Municipality of Itapiúna (Boa Água $4^{\circ} 34^{\prime} 69^{\prime \prime} S$ \& $38^{\circ} 49^{\prime} 49^{\prime \prime} \mathrm{W}$ ), Municipality of Mulungu (Bagaço $4^{\circ} 17^{\prime} 92^{\prime \prime} \mathrm{S}$

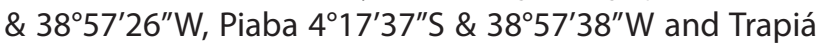
$\left.4^{\circ} 21^{\prime} 56^{\prime \prime} \mathrm{S} \& 38^{\circ} 59^{\prime} 54^{\prime \prime} \mathrm{W}\right)$ and Municipality of Pacoti (Arvoredo $4^{\circ} 13^{\prime} 78^{\prime \prime} \mathrm{S} \& 38^{\circ} 55^{\prime} 70^{\prime \prime} \mathrm{W}$ and Mulunguzinho $\left.4^{\circ} 13^{\prime} 45^{\prime \prime} \mathrm{S} \& 38^{\circ} 55^{\prime} 90^{\prime \prime} \mathrm{W}\right)$. The captures were taking weekly during one month for each locality.

The collected specimens were sent to Ceratopogonidae Collection of Instituto Oswaldo Cruz (CCER/FIOCRUZ) for identification. The morphotypes were separated using stereomicroscope Olympus SZ40. Part of specimens was slide-mounted in phenol-balsam as described by Wirth and Marston (1968) and the remaining specimens were kept in 70\% ethanol. For analyze and identification of specimens, we used Nikon Eclipse E 200 and the atlas of the wing photographs of Neotropical species of Culicoides by Wirth, Dyce, and Spinelli (1988). The slide-mounted specimens from municipalities of Baturité, Guaramiranga, Itapiúna, Mulungu and Pacoti were deposited in CCER and remaining specimens preserved in $70 \%$ ethanol, were deposited in Health Secretariat of Ceará State. Data for geographical distribution of the species were collected from the Culicoides bibliographies and more recent literature (Borkent \& Spinelli, 2007; Castellón \& Felippe-Bauer, 2015; Santarém \& Felippe-Bauer, 2018).

Ethical, conflict of interest and financial statements: the authors declare that they have fully complied with all pertinent ethical and legal requirements, both during the study and in the production of the manuscript; that there are no conflicts of interest of any kind; that all financial sources are fully and clearly stated in the acknowledgements section; and that they fully agree with the final edited version of the article. A signed document has been filed in the journal archives.

\section{RESULTS}

A total of 1453 specimens of Culicoides were collected during the sample periods, with $97,9 \%$ female and 2,1\% male specimens being captured. Twelve species were collected: C. brasilianum Forattini, 1956, C. debilipalpis, C. guyanensis, C. insignis, C. leopoldoi, C. maruim, C. paraensis, C. pifanoi Ortiz, 1951, C. phlebotomus, C. poikilonotus Macfie, 1948, C. pusillus and C. venezuelensis Ortiz \& Mirsa, 1950. Culicoides guyanensis and C. insignis were the most abundant species, corresponding respectively to $75,84 \%$ and $13 \%$ of the collected specimens. Culicoides venezuelensis represent $1,17 \%$ of the specimens captured, but it is found in five of the six surveyed Mesoregions (Tables $1 \& 2$ ).

\section{NEW RECORDS}

\section{Culicoides brasilianum Forattini, 1956}

Known geographical distribution: Northeastern Argentina, Brazil (Amazonas, Pará, Pernambuco, Rio de Janeiro, São Paulo and Santa Catarina States).

Material examined: BRAZIL, Ceará State, Mesoregion North, Municipality of São Gonçalo do Amarante, Siupé, I-II.2008, 4 females; Mesoregion Metropolitan of Fortaleza, Municipality of Aquiraz, Tupuiu, I-II.2008, 18 females [First record from Ceará State].

\section{Culicoides debilipalpis Lutz, 1913}

Known geographical distribution: Widespread from southeast USA to $35^{\circ} \mathrm{S}$ in Buenos Aires Province, Argentina, Brazil (Acre, Amapá, Amazonas, Pará, Roraima, Ceará, Maranhão, Pernambuco, Goiás, Mato Grosso do Sul, Espírito Santo, São Paulo and Santa Catarina States).

Material examined: BRAZIL, Ceará State, Mesoregion North, Municipality of Baturité, Labirinto, VI. 2013, 1 female; Municipality of Guaramiranga, Granja Bonfim, VII.2013, 1 female [First record from Guaramiranga municipality].

\section{Culicoides guyanensis Floch \& Abonnenc, 1942}

Known geographical distribution: Honduras, Panama, Venezuela, Trinidad and Tobago, Guiana, French Guiana and Brazil (Amapá, Pará, Ceará, Maranhão, Pernambuco, 


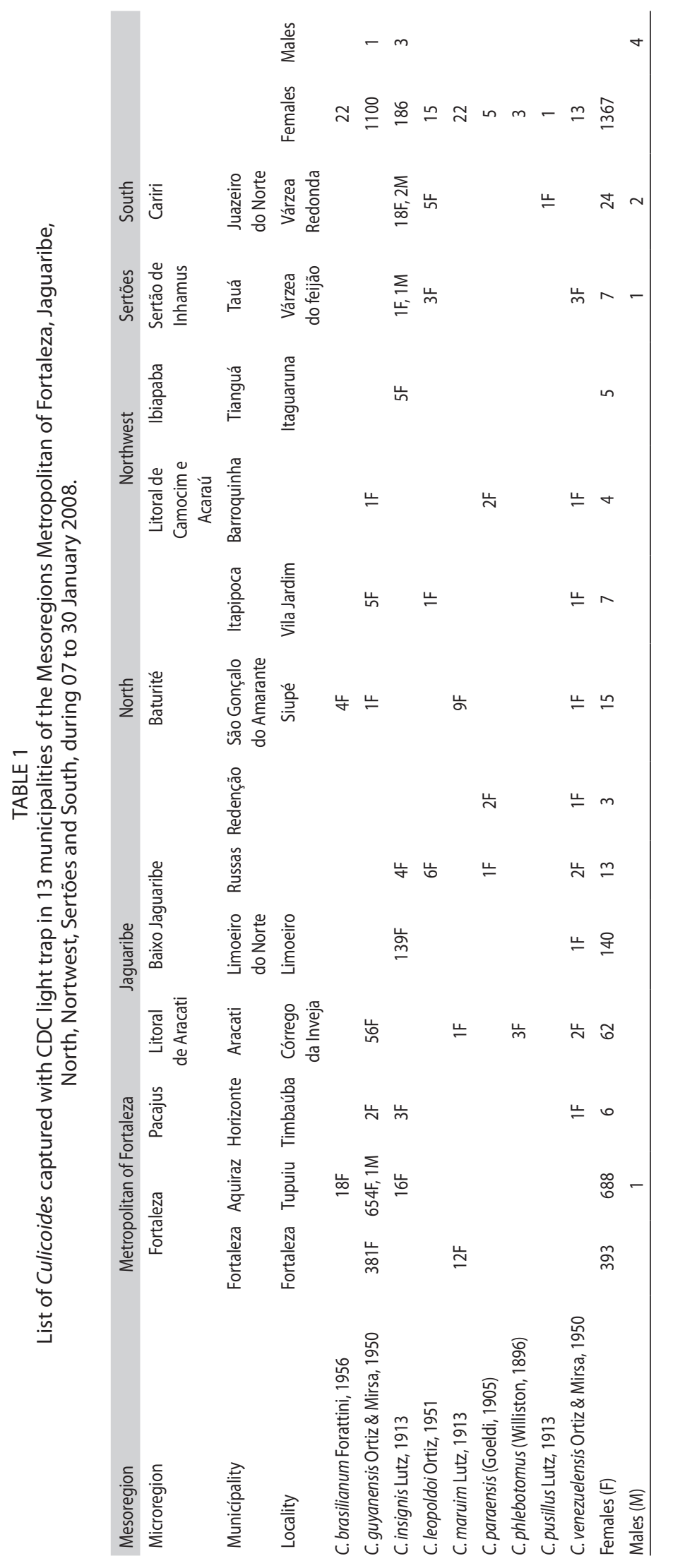




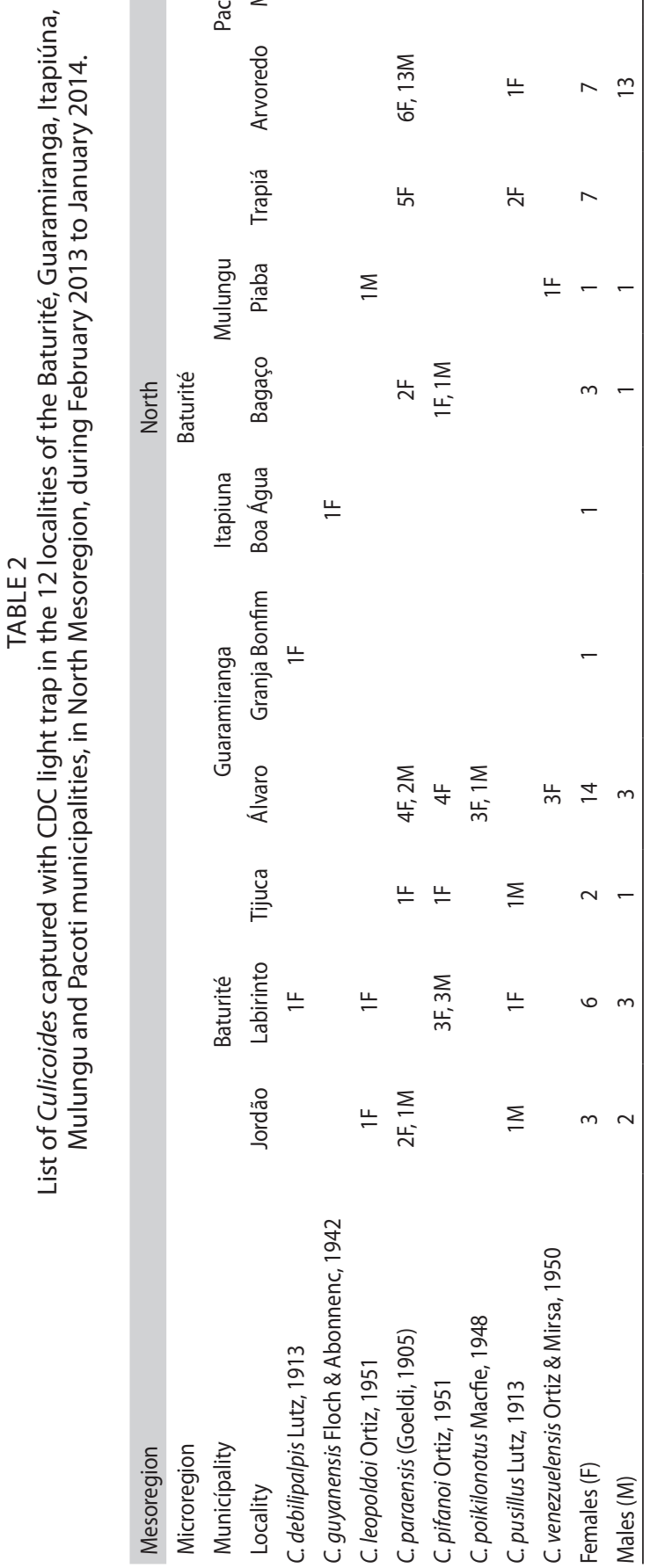

Espírito Santo, Minas Gerais, Rio de Janeiro and São Paulo States).

Material examined: BRAZIL, Ceará State, Mesoregion Metropolitan of Fortaleza, Municipality of Aquiraz, Tupuiu, I-II.2008, 654 females, 1 male; Municipality of Fortaleza, Fortaleza, I-II.2008, 381 females; Municipality of Horizonte, Timbaúba, I-II.2008, 2 females; Mesoregion Jaguaribe, Municipality of Aracatí, Córrego da Inveja, I-II.2008, 56 females; Mesoregion Northwest, Municipality of Barroquinha, I-II.2008, 1 female; Mesoregion North, Municipality of São Gonçalo do Amarante, Siupé, I-II.2008, 1 female; Municipality of Itapipoca, Vila Jardim, I-I.2008, 5 females; Municipality of Itapiuna, Boa Água, XI. 2013, 1 female [First record from Itapiuna municipality].

\section{Culicoides insignis Lutz, 1913}

Known geographical distribution: Widespread from USA (Alabama, Georgia and Florida) to $35^{\circ} \mathrm{S}$ in Argentina, Brazil (Amazonas, Pará, Maranhão, Rondônia, Bahia, Ceará, Paraíba, Pernambuco, Maranhão, Goiás, Mato Grosso, Mato Grosso do Sul, Espírito Santo, Minas Gerais, Rio de Janeiro, São Paulo, Rio Grande do Sul and Santa Catarina States).

Material examined: BRAZIL, Ceará State, Mesoregion Metropolitan of Fortaleza, Municipality of Aquiraz, Tupuiu, I-II.2008, 16 females; Municipality of Horizonte, Timbaúba, I-II.2008, 3 females; Mesoregion Sertões, Municipality of Tauá, Várzea do Feijão, I-II.2008, 1 female, 1 male; Mesoregion Jaquaribe, Municipality of Limoeiro do Norte, Limoeiro, I-II.2008, 139 females; Municipality of Russas, I-II.2008, 4 females; Mesoregion Northwest, Municipality of Tianguá, Itaguaruna, I-II.2008, 5 females; Mesoregion South, Municipality of Juazeiro do Norte, Várzea Redonda, 18 females, 2 males [First record from Aquiraz, Horizonte and Tauá municipalities and from Sertões, Jaguaribe, Northwest and South Mesoregions].

\section{Culicoides leopoldoi Ortiz, 1951}

Known geographical distribution: Widespread from Mexico (Oaxaca) to northeastern Argentina, Trinidad, Brazil (Amapá, Amazonas, Pará, Rondônia, Roraima, Bahia, Ceará, Maranhão, Pernambuco, Espírito Santo, Minas Gerais and Rio de Janeiro States).

Material examined: BRAZIL, Ceará State, Mesoregion North, Muncipality of Baturité, Jordão, II.2013, 1 female; Labirinto, VI.2013, 1 female; Municipality of Mulungu, Piaba, IX.2013, 1 male; Municipality of Pacoti, Mulunguzinho, VIII.2013, 1 female; Municipality of Itapipoca, Vila Jardim, I-II.2008, 1 female; Mesoregion 
Jaguaribe, Municipality of Russas, I-II.2008, 6 females; Mesoregion Sertões, Municipality of Tauá, Várzea do Feijão, I-II.2008, 3 females; Mesoregion South, Municipality of Juazeiro do Norte, Várzea Redonda, I-II.2008, 5 females [First record from North, Jaguaribe, Sertões and South Mesoregions].

\section{Culicoides maruim Lutz, 1913}

Known geographical distribution: Venezuela, Guiana, Guiana Francesa, Carriacou, Trinidad, Brasil (Pará, Maranhão, Bahia, Ceará, Pernambuco, Espírito Santo, Rio de Janeiro and São Paulo States).

Material examined: BRAZIL, Ceará State, Mesoregion Metropolitan of Fortaleza, Municipality of Fortaleza, Fortaleza, I-II.2008, 12 females; Mesoregion North, Muncipality of São Gonçalo do Amarante, Siupé, I-II.2008, 9 females; Mesoregion Jaguaribe, Municipality of Aracati, Córrego da Inveja, I-II.2008, 1 female [First record from Fortaleza municipality and from North and Jaguaribe Mesoregions].

\section{Culicoides paraensis (Goeldi, 1905)}

Known geographical distribution: Widespread from southeastern USA (Pennsylvania and Wisconsin) and south through Central and South America to Uruguay (Salto). Brazil records: Acre, Amazonas, Pará, Rondônia, Roraima, Bahia, Ceará, Maranhão, Pernambuco, Mato Grosso do Sul, Espírito Santo, Minas Gerais, Rio de Janeiro, São Paulo and Santa Catarina States.

Material examined: BRAZIL, Ceará State, Mesoregion North, Municipality of Baturité, Jordão, II.2013, 2 females, 1 male; Tijuca, X.2013, 1 female; Municipality of Guaramiranga, Álvaro, III, 2013, 4 females, 2 males; Municipality of Mulungu, Bagaço, V.2013, 2 females; Trapiá, I.2014, 5 females; Municipality of Pacoti, Arvoredo, XII.2013, 6 females, 13 males; Mulunguzinho, VIII.2013, 1 male; Municipality of Redenção, I-II.2008, 2 females; Mesoregion Jaguaribe, Municipality of Russas, I-II.2008, 1 female; Mesoregion Northwest, Municipality of Barroquinha, I-II.2008, 2 females [First record from Guaramiranga, Mulungu, Pacoti and Redenção municipalities, and from Jaguaribe and Northwest Mesoregions].

\section{Culicoides pifanoi Ortiz, 1951}

Known geographical distribution: Belize to Colombia, Venezuela, Trinidad, Brazil (Pará, Bahia and Rio de Janeiro States), Argentina and Paraguay.
Material examined: BRAZIL, Ceará State, Mesoregion North, Municipality of Baturité, Labirinto, VI.2013, 3 females, 3 males; Tijuca, X.2013, 1 female; Municipality of Guaramiranga, Álvaro, III, 2013, 4 females; Municipality of Mulungu, Bagaço, V.2013, 1 female, 1 male; Municipality of Pacoti, Mulunguzinho, VIII.2013, 9 females, 1 male [First record from Ceará State].

\section{Culicoides phlebotomus (Williston, 1896)}

Known geographical distribution: Distributed from costal Mexico to Ecuador, Caribe Islands, Guiana, Brazil (Pará, Maranhão, Ceará, Pernambuco and Goiás States).

Material examined: BRAZIL, Ceará State, Mesoregion Jaguaribe, Municipality of Aracati, Córrego da Inveja, I-II.2008, 3 females [First record from Jaguaribe Mesoregion].

\section{Culicoides poikilonotus Macfie, 1948}

Known geographical distribution: Distributed from Mexico, Central America, Venezuela, Colombia, Trinidad to Brazil (Bahia and Rio de Janeiro States).

Material examined: BRAZIL, Ceará State, Mesoregion North, Municipality of Guaramiranga, Álvaro, III.2013, 3 females, 1 male [First record from Ceará State].

\section{Culicoides pusillus Lutz, 1913}

Known geographical distribution: Widespread from USA (Florida), Mexico and south through Central and South America to northeastern Argentina. Brazil records: Acre, Amapá, Amazonas, Pará, Rondônia, Bahia, Minas Gerais, Rio de Janeiro, São Paulo and Santa Catarina States).

Material examined: BRAZIL, Ceará State, Mesoregion North, Municipality of Baturité, Jordão, II.2013, 1 male; Labirinto, VI.2013, 1 female; Tijuca, X. 2013, 1 male; Municipality of Mulungu, Trapiá, 1.2014, 2 females; Municipality of Pacoti, Arvoredo, XII.2013, 1 female; Mulunguzinho, VIII.2013, 1 male; Mesoregion South, Municipality of Juazeiro do Norte, Várzea Redonda, I-II.2008, 1 female [First record from Ceará State].

\section{Culicoides venezuelensis Ortiz \& Mirsa, 1950}

Known geographical distribution: Costa Rica to Chile and Central Argentina, Brazil (Pernambuco, Minas Gerais, São Paulo, Rio Grande do Sul and Santa Catarina States).

Material examined: BRAZIL, Ceará State, Mesoregion North, Municipality of Guaramiranga, Álvaro, III.2013, 3 females; Municipality of Mulungu, Piaba, IX. 2013, 
1 female; Municipality of Redenção, I-II.2008, 1 female; Municipality of São Gonçalo do Amarante, Suipé, I-II.2008, 1 female; Municipality of Itapipoca, Vila Jardim, I-II.2008, 1 female; Mesoregion Metropolitan of Fortaleza, Municipality of Horizonte, Timbaúba, I-II.2008, 1 female; Mesoregion Jaguaribe, Municipality of Aracati, Córrego da Inveja, I-II.2008, 2 females; Municipality of Limoeiro do Norte, Limoeiro, I-II.2008, 1 female; Municipality of Russas, I-II.2008, 2 females; Mesoregion Northwest, Municipality of Barroquinha, I-II.2008, 1 female; Mesoregion Sertões, Municipality of Tauá, Várzea do Feijão, I-II.2008, 3 females [First record from Ceará State].

\section{DISCUSSION}

Culicoides debilipalpis was reported from Baturité Mountains and Uruburetama municipality from North Mesoregion (Barbosa, 1953). In the present work, this species is found in Baturité and Guaramiranga, municipalities. Culicoides pifanoi was exclusively observed on Baturité, Guaramiranga, Mulungu and Pacoti municipalities in North Mesoregion, while C. poikilonotus was captured only in Guaramiranga (Table 2). All these municipalities encompass the cities from Baturité Mountains influenced by humid climate from Rain forest prevailing in this region.

Despite its wide distribution in Brazil, C. guyanensis was only registered recently from Ceará State to the municipalities of Jaguaribe, Metropolitan of Fortaleza, Northwest and North Mesoregions (Santarém, Farias, \& Felippe-Bauer, 2015). It is cited for the first time in this work from Itapiuna municipality in North Mesoregion (Table 2).C.insignis, anteriorly reported from Metropolitan of Fortaleza and North Mesoregions (Barbosa, 1953; Forattini, 1957), is founded here in Sertões, Jaguaribe, Northwest and South Mesoregions (Table 1). Culicoides guyanensis and $C$. insignis can be reared in fresh and brackish water, open to sky (Forattini, Rabello, \& Pattoli, 1958; Williams, 1964) and in mangrove (Forattini, Rabello, \& Pattoli, 1957), which explains its wide distribution in the studied mesoregions in coastal cities as well as within the Ceará State. Felippe-Bauer and Sternheim (2008) also associate the presence of $C$. insignis with the irrigated rice plantation in Santa Catarina State, Brazil.

Culicoides insignis and C. pusillus are incriminated as possible vector of bluetongue in South America (Mellor, 2004). C. pusillus is recorded for the first time in Ceará State, where goats and sheep positive serology for bluetongue virus was demonstrate (Pinheiro, Chagas,
Andrioli, \& Alves, 2003). In the present work, it was captured in Juazeiro do Norte in South Mesoregion and in the municipalities of Baturité, Mulungu and Pacoti in North Mesoregion (Table $1 \&$ 2). It can be reared in decaying parts of several plants as banana, cocoa, calabash, coconut, flowers and also in humid cow and horse manure, mangrove mud (Williams, 1964).

Culicoides leopoldoi was mentioned from Pacatuba municipality of Metropolitan of Fortaleza Mesoregion (Forattini, 1957) and is cited for the first time in this survey from North, Jaguaribe, Sertões, and South Mesoregions (Table $1 \& 2$ ). This species can be reared from margins of ditches and small streams of various sorts (Williams, 1964; Aitken, Wirth, Williams, Davies, \& Tikasingh, 1975). It is widespread in Central and South America and seems don't have epidemiological importance in the transmission of disease to man and other animals.

Culicoides maruim and C. phlebotomus are considered as coastal species (Borkent \& Spinelli, 2007). C. maruim was cited from Caucaia (Barbosa, 1953) and C. phlebotomus from Cascavel (Forattini, 1957), costal municipalities of the Metropolitan of Fortaleza Mesoregion. In this study, few specimens of C. maruim were captured in coastal localities from municipalities of Aracati (Córrego da Inveja), Fortaleza (Fortaleza) and São Gonçalo do Amarante (Siupé). C. phlebotomus was only captured in Córrego da Inveja (Table 1).

Culicoides venezuelensis was present in five of the six Mesoregions studied, being recorded in coastal and within municipalities of the Ceará State (Table 1 \& 2). Diaz, Ronderos, and Spinelli (2005) cited this species reared in muddy area near a stream margin and Ronderos, Marino, Díaz and Estévez (2011) collected imatures stages in inland aquatic habitat near river margins produced by river overflows and rainfall.

Culicoides paraensis was recorded from Serra do Baturité and Uruburetama in North Mesoregion (Barbosa, 1953) and from Quixadá in Sertões Mesoregion (Forattini, 1957). In this survey, it is also collected in Jaguaribe and Northwest Mesoregions (Table 1). This species is present in natural environments, but it is considered pest species in areas of banana monoculture, which is enabling environments on large scale for the development of immature stages (Felippe-Bauer \& Sternheim, 2008). C. paraensis transmits the Oropouche virus between humans in urban areas of the Brazilian Amazon and other Latin American countries where more than 30 epidemics were reported (Vasconcelos et al., 2009, 2011). Its presence in the neighboring state to the Amazon region is indicative of the possible spread of this arbovirosis to other regions. 


\section{ACKNOWLEDGMENTS}

We thank the Vector Control Center of the Health Secretariat of Ceará State and the staff of the Health's Secretariat from Aracati, Baturité, Fortaleza, Itapipoca, Juazeiro do Norte, Limoeiro, Tauá and Tianguá municipalities for helping on the fieldworks and for logistical assistance. Tiago do Nascimento da Silva for confection and edition of map. We also thank to "Sistema de Informação sobre a Biodiversidade Brasileira" ( $\mathrm{SiBBr}$ ) and "Banco Nacional de Desenvolvimento Econômico e Social" (BNDES) for financial support.

\section{REFERENCES}

Aitken, T.H.G., Wirth, W.W., Williams, R.W., Davies, J.B., \& Tikasingh, E.S. (1975). A review of the bloodsucking midges of Trinidad and Tobago, West Indies (Diptera: Ceratopogonidae). Journal of Entomology (B), 44(2), 101144. DOI: $10.1111 /$ j.1365-3113.1975.tb00007.x

Barbosa, F.A.S. (1953). Novos subsídios para o conhecimento dos Culicoides neotrópicos (Diptera: Heleidae). Publicações Avulsas do Instituto Aggeu Magalhães, 2(3), 11-42.

Borkent, A. (2016). The Subgeneric Classification of Species of Culicoides - thoughts and a warning. Retrieved from http://wwx.inhs.illinois.edu/files/5014/6532/8290/ CulicoidesSubgenera.pdf

Borkent, A., \& Spinelli, G.R. (2007). Neotropical Ceratopogonidae (Diptera: Insecta). In J. Adis, J. R. Arias, G. Rueda-Delgado, \& K. M. Wnatzen (Eds.), Aquatic Biodiversity in Latin America (ABLA) 4 (pp. 1-198). Sofia-Moscow: Pensoft.

Castellón, E.G., \& Felippe-Bauer, M.L. (2015). Classificação e distribuição das espécies de Culicoides (Diptera: Ceratopogonidae) na Amazônia Brasileira ou Amazônia Legal. In E. G. Castellón \& R. S. Veras (Eds.), Maruins (Culicoides: Ceratopogonidae) na Amazônia Brasileira (pp. 29-73). Manaus: Editora INPA.

Diaz, F., Ronderos, M.M., \& Spinelli, G.R. (2005). The immatures of Neotropical species Culicoides venezuelensis Ortiz \& Mirsa (Diptera: Ceratopogonidae). Transactions of the American Entomological Society, 131(3/4), 375-385.

Felippe-Bauer, M.L., \& Sternheim, U.S. (2008). Culicoides paraensis (Diptera: Ceratopogonidae) infestations in cities of the Itapocú River Valley, southern Brazil. Entomological News, 119(2), 185-192. DOI: 10.3157/0013-872X(2008)119[185:CPDCII]2.0.CO;2

Forattini, O.P. (1957). Culicoides da Região Neotropical (Diptera, Ceratopogonidae). Arquivos da Faculdade de Higiene e Saúde Pública da Universidade de São Paulo, 11, 159-526. DOI: 10.11606/issn.2358-792X.v11i2p161-526
Forattini, O.P., Rabello, E.X., \& Pattoli, D. (1957). A brief note on breeding places of Culicoides in São Vicente, Brazil. Mosquito News, 17, 312-313.

Forattini, O.P., Rabello, E.X., \& Pattoli, D. (1958). Culicoides da região neotropical (Diptera: Ceratopogonidae). II Observações sobre biologia sobre condições naturais. Arquivos da Faculdade de Higiene e Saúde Pública da Universidade de São Paulo, 12, 1-52. DOI: 10.11606/issn.2358-792X.v12i1p1-52

Mellor, P.S. (2004). Infection of the vectors and bluetongue epidemiology in Europe. Epidemiology and vectors 40(3), 167-174.

Pinheiro, R.R., Chagas, A.C.S., Andrioli, A., \& Alves, F.F. (2003). Viroses de pequenos ruminantes. Embrapa Caprinos, 46,1-30.

Ronderos, M.M., Marino, P.I., Díaz, F., \& Estévez, A.L. (2011). Biting midges (Diptera: Ceratopogonidae) from Martín García Island, Argentina. Revista de Biología Tropical, 59(3), 1183-1194.

Santarém, M.C.A., Farias, E.S., \& Felippe-Bauer, M.L. (2015). Culicoides castelloni sp. nov. from the Brazilian Amazon Region with a revision of the reticulatus species group (Diptera, Ceratopogonidae). Anais da Academia Brasileira de Ciências, 87(2), 955-972. DOI: 10.1590/0001-3765201520140517

Santarém, M.C.A., \& Felippe-Bauer, M.L. (2018). Brazilian species of biting midges. Retrieved from https://portal.fiocruz. $\mathrm{br} / \mathrm{sites} /$ portal.fiocruz.br/files/documentos/brazilian_ species_of_biting_midges_2018_.pdf

Vasconcelos, H.B., Azevedo, R.S.S., Casseb, S.M., Nunes-Neto, J.P., Chiang, J.O., Cantuária, P.C., ... Vasconcelos, P.F.C. (2009). Oropouche fever epidemics in Northern Brazil: Epidemiology and molecular characterization of isolates. Journal of Clinical Virology, 44, 129-133. DOI: 10.1016/j.jcv.2008.11.006

Vasconcelos, H.B., Nunes, M.R., Casseb, L.M.N., Carvalho, V.L., Silva, E.V.P., Silva, M., \& Vasconcelos, P.F.C. (2011). Molecular Epidemiology of Oropouche Virus, Brazil. Emerging Infectious Deseases, 17(5), 800-806. DOI: 10.3201/eid1705.101333

Williams, R.W. (1964). Observations on Habitats of Culicoides Larvae in Trinidad, W. I. (Diptera: Ceratopogonidae). Annals of the Entomological Society of America, 57, 462-466.

Wirth, W.W., Dyce, A.L., \& Spinelli, G.R. (1988). An Atlas of wing photographs, with a summary of the numerical characters of the Neotropical species of Culicoides (Diptera: Ceratopogonidae). Contributions of the American Entomological Institute, 25(1), 1-72.

Wirth, W.W., \& Marston, N. (1968). A method for mounting small insects on microscope slides in Canada Balsam. Annals of the Entomological Society of America, 61, 783-784. DOI: 10.1093/aesa/61.3.783 